$11-1-2017$

\title{
Influence of the megathrust earthquake cycle on upper-plate deformation in the Cascadia forearc of Washington State, USA
}

Jaime E. Delano

Western Washington University

Colin B. Amos

Western Washington University

John P. Loveless

Smith College, jloveles@smith.edu

Tammy M. Rittenour

Utah State University

Brian L. Sherrod

University of Washington

See next page for additional authors

Follow this and additional works at: https://scholarworks.smith.edu/geo_facpubs

Part of the Geology Commons

\section{Recommended Citation}

Delano, Jaime E.; Amos, Colin B.; Loveless, John P.; Rittenour, Tammy M.; Sherrod, Brian L.; and Lynch, Emerson M., "Influence of the megathrust earthquake cycle on upper-plate deformation in the Cascadia forearc of Washington State, USA" (2017). Geosciences: Faculty Publications, Smith College, Northampton, MA.

https://scholarworks.smith.edu/geo_facpubs/24 
Authors

Jaime E. Delano, Colin B. Amos, John P. Loveless, Tammy M. Rittenour, Brian L. Sherrod, and Emerson M. Lynch 


\section{Influence of the megathrust earthquake cycle on upper plate}

\section{2 deformation in the Cascadia forearc of Washington State}

\section{Jaime E. Delano ${ }^{1}$, Colin B. Amos ${ }^{1}$, John P. Loveless ${ }^{2}$, Tammy M. Rittenour ${ }^{3}$, Brian}

4 L. Sherrod ${ }^{4}$, and Emerson M. Lynch ${ }^{2}$

$5{ }^{1}$ Department of Geology, Western Washington University, 516 High Street, Bellingham,

6 Washington 98225, USA

$7 \quad{ }^{2}$ Department of Geosciences, Smith College, 44 College Lane, Northampton,

8 Massachusetts 01063, USA

$9{ }^{3}$ Department of Geology, Utah State University, 4505 Old Main Hill, Logan, Utah 84322,

$10 U S A$

$11{ }^{4}$ U.S. Geological Survey, Department of Earth and Space Sciences, University of

12 Washington, Box 351310, Seattle, Washington 98195, USA

\section{ABSTRACT}

14 The influence of subduction zone earthquake cycle processes on permanent

15 forearc deformation is poorly understood. In the Cascadia subduction zone forearc of

16 Washington State, deformed and incised fluvial terraces serve as archives of longer-term

$17\left(10^{3}-10^{4} \mathrm{yr}\right)$ strain manifest as both fluvial incision and slip on upper-plate faults. We

18 focus on comparing these geomorphic records in the Wynoochee River valley in the

19 southern Olympic Mountains with short-term $\left(10^{1} \mathrm{yr}\right)$ deformation driven by interseismic

20 subduction zone coupling. We use optically stimulated luminescence dating and high-

21 resolution elevation data to characterize strath terrace incision and differential uplift

22 across the Canyon River fault, which cuts Wynoochee River terraces. This analysis 
23 demonstrates reverse slip rates of $\sim 0.1-0.3 \mathrm{~mm} / \mathrm{yr}$ over the past $\sim 12-37 \mathrm{ky}$, which agree

24 with rates predicted by a GPS-constrained boundary element model of interseismic stress

25 from Cascadia subduction zone coupling. Similarly, model-predicted patterns of

26 interseismic uplift mimic the overall pattern of incision in the lower Wynoochee River

27 valley, as revealed by strath elevations dated at $14.1 \pm 1.2 \mathrm{ka}$. Agreement between

28 modeled short-term and observed long-term records of forearc strain suggests that

29 interseismic stress drives slip on upper-plate faults and fluvial incision in Cascadia.

30 Consistency over multiple time scales may indicate relative stability in spatial patterns of

31 subduction zone coupling over at least $\sim 10^{4} \mathrm{yr}$ intervals.

\section{INTRODUCTION}

33 A comprehensive picture of deformation, topographic development, and seismic

34 hazard in subduction zone forearcs requires understanding strain over multiple time

35 intervals. Although interseismic deformation above a subduction zone is considered to be

36 largely elastic (e.g., Mazzotti et al., 2002; Mitchell et al., 1994), some fraction may be

37 retained as permanent strain over multiple earthquake cycles (e.g., Kelsey et al., 1994;

38 Melnick et al., 2009). Records of incremental deformation preserved in Quaternary

39 forearc landforms may encode information about the relative stability of shorter-term

$40 \quad\left(10^{1}-10^{3} \mathrm{yr}\right)$ processes such as interseismic strain, segmentation of megathrust ruptures,

41 and upper-plate faulting (Personius, 1995).

42 The relationship between deformation from the megathrust earthquake cycle and

43 Holocene-active forearc faults and folds is poorly quantified. Forearc structures may

44 accommodate margin-normal and/or parallel slip related to the orientation of plate

45 convergence (e.g., McCaffrey, 1993) and may be sensitive to stress induced by great 
46 subduction earthquakes (Aron et al., 2013; Loveless and Pritchard, 2008). Accordingly,

47 megathrust earthquakes may trigger slip on forearc faults (Sherrod and Gomberg, 2014),

48 or conversely, ruptures on upper-plate structures may initiate subduction earthquakes by

49 decoupling the megathrust (González et al., 2015). Forearc structures may also serve as

50 boundaries that control the length and location of subduction zone ruptures over multiple

51 earthquake cycles (Melnick et al., 2009).

52 In this study, we quantify deformation in the Wynoochee River valley in the

53 southern Olympic Mountains of Washington State (Fig. 1) using lidar data, optically

54 stimulated luminescence (OSL) dating, and cm-scale terrace-strath surveys. We calculate

55 longer-term ( $\left.\geq 10^{3} \mathrm{yr}\right)$ slip on the upper-plate Canyon River fault (CRF) and fluvial

56 downcutting for comparison with decadal-scale, modeled interseismic deformation from

57 the Cascadia subduction zone (CSZ). We utilize a boundary element method (Crouch and

58 Starfield, 1983; Thomas, 1993) model to infer upper-plate fault slip needed to relieve

59 stress from subduction zone coupling estimated from GPS observations, as well as

60 regional interseismic uplift. Together, these results provide an explicit examination of

61 links between CSZ-related deformation, forearc fault slip, and fluvial incision.

\section{BACKGROUND}

63 Geodetic measurements show that the CSZ accommodates NE-SW oblique

64 convergence between the Juan de Fuca and N. American plates (Fig. 1 inset). Geodetic-

65 geomorphic comparisons in Oregon imply that small amounts of interseismic strain

66 persist over multiple earthquake cycles, rather than being entirely elastic (Kelsey et al.,

67 1994). Permanent deformation in the CSZ forearc reflects some combination of slip on

68 upper-plate faults (e.g., Wells et al., 1998), wedge accretion manifest as underplating or 
69 aseismic folding (Hyndman and Wang, 1993; Pazzaglia and Brandon, 2001), and poorly

70 understood contributions from the megathrust earthquake cycle.

71 Records of uplift in the Olympic Mountains, the topographic high of the CSZ

72 forearc, include both thermochronologic measurements at $\sim 10^{6} \mathrm{yr}$ time scales (Brandon et

73 al., 1998) and river incision records at $\sim 10^{3}-10^{5}$ yr scales (Pazzaglia and Brandon, 2001).

74 These studies demonstrate that incision rates broadly agree with longer term exhumation

75 rates, implying steady-state erosion over millennial and perhaps longer time scales.

76 Within the Olympic Peninsula are east and NE-striking reverse, strike-slip, and

77 oblique-slip faults that together accommodate trench-parallel shortening implied by

78 obliquity in plate convergence (Fig. 1) (e.g., Barnett et al., 2015; Blakely et al., 2009;

79 Witter et al., 2008). Previous studies in Cascadia proposed that upper-plate fault slip

80 arises from the deficit between plate convergence and trench-normal megathrust

81 earthquake rebound (e.g., Mazzotti et al., 2002; Wang et al., 1995). Alternatively,

82 curvature in the subducting slab (Bevis et al., 2001) and associated oroclinal bending

83 could focus interseismic trench-parallel shortening on upper-plate structures

84 (Allmendinger et al., 2005).

85 The NE-striking CRF represents one such fault in the southern Olympic

86 Mountains (Fig. 1), accommodating south-side-up reverse or oblique motion (Walsh and

87 Logan, 2007), similar to faults in Puget Lowlands (Fig. 1). Airborne lidar (Quinault River

88 Basin, 2012; Southwest Washington, 2009) reveals a previously unmapped strand of the

89 CRF that cuts terraces along the Wynoochee River, a prominent N-S drainage with

90 headwaters in the southern Olympic Mountains (Figs. 1 and 2). The Wynoochee River

91 basin contains several generations of alpine glacial moraines, aggradational fills and 
92 glaciolacustrine deposits, and degradational strath terraces (Carson, 1970). To explore

93 potential links between the geomorphology of this area and the CSZ earthquake cycle, we

94 compare the record of faulting and incision to deformation from interseismic subduction

95 zone coupling.

\section{DECADAL AND MILLENNIAL SLIP ON THE CANYON RIVER FAULT}

97 Our mapping of the CRF reveals a segmented, steeply south-dipping fault with

98 south-side-up reverse displacement indicated by offset terraces. The emergence of a

99 narrow canyon and associated knickpoint downstream of the fault (Figs. 2 and $3 b$ ) is also

100 consistent with south-side-up displacement as the stream must narrow, steepen, and

101 incise to compensate for relatively faster uplift (e.g., Amos and Burbank, 2007). We

102 mapped eight generations of terraces (Qt1 to Qt8), some containing minor subset cut-in-

103 fill terraces denoted by ' $b$ ' and 'c.' We calculate dip-slip rate on the CRF using

104 topographic profiles extracted from the lidar, OSL ages (Table 1) derived from standard

105 sampling and lab procedure (Figs. DR1-DR8; Appendix DR1), and fault dip estimated

106 from trenching (Walsh and Logan, 2007). Though Walsh and Logan (2007) observed

107 oblique, sinistral-reverse slickenlines on the CRF $\sim 10 \mathrm{~km}$ to the east, no laterally offset

108 features are observed in the Wynoochee valley.

109 Topographic profiles along terrace surfaces cut by the CRF (Fig. 2, profiles A-P)

110 yield vertical separations of $\sim 0.9-6.1 \mathrm{~m}$ (Fig. 2a; Table DR3, Appendix DR1). In

111 combination with OSL ages from the Qt8, Qt7, and Qt4 terraces (Table 1), these

112 measurements suggest vertical separation rates of $\sim 0.1-0.4 \pm 0.1 \mathrm{~mm} / \mathrm{yr}$ (Fig. 2a, Table

113 DR3). Uncertainty in matching the Qt5 terrace across the CRF yields vertical separations

114 of $4.3 \pm 1.6-7.7 \pm 3.5 \mathrm{~m}$, depending on the continuity of the northern terrace tread with 
115 Qt5 and Qt5b south of the fault (Fig. 2c). These profiles give vertical separation rates of

$1160.3+0.2 /-0.1$ and $0.5+0.3 /-0.2 \mathrm{~mm} / \mathrm{yr}$, respectively, using the offset Qt5 deposit age of

$11714.8 \pm 2.0 \mathrm{ka}$ (WYN-06). Based on a range of fault dips from 55 to $85^{\circ} \mathrm{S}$, encompassing

118 the observed $70^{\circ} \mathrm{S}$ dip from Walsh and Logan (2007), the median reverse slip rate for all

119 profiles is $0.2 \mathrm{~mm} / \mathrm{yr}$ (Table DR3). Since OSL sample burial predates modern tread

120 formation, OSL-derived separation rates are regarded as minima (Appendix DR1).

121 To test the relationship between slip on the CRF and the underlying CSZ, we use

122 a boundary element method model (e.g., Crouch and Starfield, 1983) to calculate stress

123 imposed on the CRF by interseismic coupling on the CSZ (Fig. DR9) estimated using a

124 geodetically constrained block model (Meade and Loveless, 2009). We then estimate slip

125 rates on the CRF required to relieve the imposed stress, assuming that the CRF is a shear

126 traction-free surface (details in Appendix DR1), similar to studies of the San Andreas

127 fault system (e.g., Cooke and Dair, 2011). The resulting slip rate distribution represents

128 that of CRF earthquake(s) normalized by recurrence interval, assuming slip completely

129 relieves accumulated shear stress imposed by CSZ coupling. Using a nominal $70^{\circ} \mathrm{S}$ fault

130 dip and $10 \mathrm{~km}$ fault depth, the model predicts south-side-up motion, with estimated

131 reverse slip rates of $0.1-0.5 \mathrm{~mm} / \mathrm{yr}$ (Fig. DR10). At the Wynoochee River, estimated

132 reverse slip is $\sim 0.1-0.2 \mathrm{~mm} / \mathrm{yr}$. The lateral component of estimated slip ranges up to 0.7

$133 \mathrm{~mm} / \mathrm{yr}$ of dextral motion (Fig. DR10). We tested alternative fault depths and connectivity

134 to consider uncertainty in fault geometry (Appendix DR1). These variations yield the

135 same slip sense (reverse-dextral) and slip rates of similar magnitude and within the

136 geomorphic uncertainty.

\section{INCISION AND UPLIFT OF THE WYNOOCHEE RIVER VALLEY}


We use terrace strath incision along the Wynoochee River to estimate long-term

$139\left(10^{3}-10^{4} \mathrm{yr}\right)$ vertical uplift and compare to modeled interseismic uplift (Fig. 3). This

140 analysis uses the elevation of the Qt5 strath, the most continuous and best-exposed

141 terrace in the Wynoochee valley. Strath heights come from high-resolution differential

142 GPS field surveys and well log data (Table DR4) (Washington State Dept. of Ecology,

143 2015). In the upper reaches of the Wynoochee River $(<20 \mathrm{~km})$, the Qt5 terrace deposit

144 contains a thick aggradational fill $(\sim 5-20 \mathrm{~m})$ deposited on fine-grained glaciolacustrine

145 deposits and basalt (Fig. 3b). Incised glacial deposits beneath Qt5 fill suggest alternating

146 periods of vertical incision, aggradation, and valley re-excavation, resulting in artificially

147 high incision rates. We therefore focus on the overall rate and pattern of incision in the

148 lower reaches of the river $(>20 \mathrm{~km})$, where relatively thin fluvial deposits overlie straths

149 incised into sedimentary bedrock (Fig. 3b). Here, OSL dates provide the minimum strath

150 abandonment age and therefore maximum incision rates (e.g., Litchfield and Berryman,

151 2006).

152 Incision of the Qt5 strath, calculated by subtracting the channel elevation from the

153 strath elevation, varies along the length of the Wynoochee River (Fig. 3c). Discrepancy

154 between strath offset and Qt5 terrace tread offset ( 4-7 m, Fig. 2c) across the CRF

155 supports our inference of diachronous strath cutting below Qt5 in the glacially

156 influenced, upper reaches of the river $(<20 \mathrm{~km})$. Where strath incision is potentially more

157 straightforward to interpret downstream, the Qt5 strath shows broad warping over a half

158 wavelength of $\sim 30 \mathrm{~km}$ (Fig. 3c). The range of Qt5 strath heights incised into sedimentary

159 bedrock corresponds to incision rates of $0.4 \pm 0.3-1.8 \pm 0.3 \mathrm{~mm} / \mathrm{yr}$, assuming 
160 simultaneous tread abandonment and using an average Qt5 OSL age of $14.1 \pm 1.2 \mathrm{ka}$

161 (Fig. 3c, Appendix DR1).

162 Modeled uplift rates representing combined effects of CSZ coupling and CRF slip

163 are $\sim 2.1-2.8 \mathrm{~mm} / \mathrm{yr}$ along the Wynoochee valley (Fig. 3a,c). This total rate reflects

164 interseismic uplift plus an average annual contribution from CRF earthquakes.

165 Interseismic uplift rates generally decrease to the east with increasing distance from

166 strong CSZ coupling (Fig. DR11), but south-side-up motion on the CRF introduces some

167 deviation from this pattern. Notably, the Wynoochee River flows through a local

168 minimum in model-predicted uplift, owing to segmentation of the CRF within the valley

169 (Fig. 3a).

\section{DISCUSSION}

171 Similarities in rates and patterns of Late Pleistocene faulting and incision and the

172 predicted deformation from the model suggest that interseismic subduction zone coupling

173 may drive permanent forearc fault slip and uplift. On the CRF, reverse slip rates inferred

174 from terrace offsets ( $0.2 \mathrm{~mm} / \mathrm{yr}$; Fig. 2$)$ closely match the model rates $(0.1-0.2 \mathrm{~mm} / \mathrm{yr})$

175 (Fig. 3a). These rates are consistent with those of similarly oriented structures in the SE

176 Olympic Mountains, including the Saddle Mountain fault, which displays post-glacial

177 vertical deformation rates of $\sim 0.2 \mathrm{~mm} / \mathrm{yr}$ (Barnett et al., 2015).

178 The general match in reverse slip rates across multiple timescales suggests that

179 interseismic stress from the coupled subduction zone may alone cause upper-plate fault

180 slip in the forearc; no additional driving mechanisms, such as CSZ coseismic slip (Figs.

181 DR13-14, Appendix DR1) or crustal block motions, are required to produce the observed

182 reverse slip on the CRF. The predicted component of dextral slip on the CRF from the 
183 model, however, does not match observed sinistral-reverse slickenlines (Walsh and

184 Logan, 2007). That said, lateral slip is poorly recorded in Holocene landforms and

185 potentially varies along-strike, between the coseismic and interseismic phase of the

186 megathrust earthquake cycle, and/or over multiple earthquake cycles. As such, we focus

187 here on predicted reverse motion on the CRF driven by subordinate trench-parallel

188 convergence due to subduction zone coupling. Reverse slip on the CRF also compares

189 well with geomorphic evidence of continued, south-side-up reverse motion on the CRF

190 (Fig. 2).

191 Several factors complicate the degree to which fluvial downcutting recorded by

192 Wynoochee terraces (Fig. 3) reflects tectonic uplift. The presence of aggradational fills

193 and evidence for repeated glaciation, particularly in the upper basin (Carson, 1970),

194 suggest that a component of incision may result from glacial isostatic adjustment from

195 local alpine glaciers and/or the Puget Lobe of the Cordilleran ice sheet $(<35 \mathrm{~km}$ to the

196 east; Fig. 1) (Thorson, 1989). Additionally, the prevalence of bedrock incision along the

197 entire length of the Wynoochee River (Fig. 3c) reflects climactic factors such as long-

198 term base level lowering from sediment loss at the river mouth (Carson, 1970), or

199 gradient decrease from headwater sediment loss. Incision rates are also calculated over

200 half a glacial cycle, and are thus overestimates. Given these factors, we focus on

201 comparing overall spatial patterns of incision and interseismic uplift rather than the

202 absolute rates.

203 Neither isostasy nor base level change, however, likely produces the broad, $\sim 15-$

$20420 \mathrm{~m}$ warping of the Qt5 terrace strath in the lower Wynoochee River (Fig. 3c). Although

205 this feature could reflect motion on a blind fault, we note a correlation between incision 
206 and predicted interseismic uplift along the Wynoochee valley (Fig. 3c and inset).

207 Combined with the location of the Wynoochee River at a local minimum in total modeled

208 uplift (Fig. 3a), such spatial coincidence suggests that terrace downcutting mimics short-

209 term strain patterns. This result resembles previous findings based on geomorphic

210 observations in Oregon (Kelsey et al., 1994; Personius, 1995).

211 Our results imply that long-term $\left(>10^{3} \mathrm{yr}\right)$ forearc deformation, including trench-

212 parallel shortening expressed as reverse faulting, broad scale folding, and uplift of the

213 Olympic Mountains represents a permanent component of interseismic strain. Hence,

214 deformation in the Cascadia forearc could express long-lived, temporally stable patterns

215 of interplate coupling.

\section{ACKNOWLEDGMENTS}

217 We thank Nicola Litchfield, Juliet Crider, Rich Briggs, and anonymous referees

218 for helpful reviews; the Green Diamond Resource Co. for access; the Puget Sound Lidar

219 Consortium for hosting lidar data; and Tabor Reedy, Kaelin Newman, and Scott Bennett

220 for help and discussions in the field. OSL dating was supported by the EarthScope AGeS

221 Program.

\section{REFERENCES CITED}

223 Allmendinger, R.W., González, G., Yu, J., Hoke, G., and Isacks, B., 2005, Trench-

224 parallel shortening in the Northern Chilean Forearc: Tectonic and climatic

225 implications: Geological Society of America Bulletin, v. 117, p. 89-104,

226 doi:10.1130/B25505.1. 
227 Amos, C.B., and Burbank, D.W., 2007, Channel width response to differential uplift:

228 Journal of Geophysical Research, Earth Surface, v. 112, p. F02010,

229 doi:10.1029/2006JF000672.

230 Aron, F., Allmendinger, R.W., Cembrano, J., González, G., and Yáñez, G., 2013,

231 Permanent fore-arc extension and seismic segmentation: Insights from the 2010

232 Maule earthquake, Chile: Journal of Geophysical Research, v. 118, p. 724-739,

233 doi:10.1029/2012JB009339.

234 Barnett, E.A., Sherrod, B.L., Hughes, J.F., Kelsey, H.M., Czajkowski, J.L., Walsh, T.J.,

235 Contreras, T.A., Schermer, E.R., and Carson, R.J., 2015, Paleoseismic Evidence for

236 Late Holocene Tectonic Deformation along the Saddle Mountain Fault Zone,

237 Southeastern Olympic Peninsula, Washington: Bulletin of the Seismological Society

238 of America, v. 105, p. 38-71, doi:10.1785/0120140086.

239 Bevis, M., Kendrick, E., Smalley, R., Brooks, B., Allmendinger, R., and Isacks, B., 2001,

240 On the strength of interplate coupling and the rate of back arc convergence in the

241 central Andes: An analysis of the interseismic velocity field: Geochemistry

242 Geophysics Geosystems, v. 2, p. 1067, doi:10.1029/2001GC000198.

243 Blakely, R.J., Sherrod, B.L., Hughes, J.F., Anderson, M.L., Wells, R.E., and Weaver,

244 C.S., 2009, Saddle Mountain fault deformation zone, Olympic Peninsula,

245 Washington: Western boundary of the Seattle uplift: Geosphere, v. 5, p. 105-125,

246 doi:10.1130/GES00196.1.

247 Brandon, M.T., Roden-Tice, M.K., and Garver, J.I., 1998, Late Cenozoic exhumation of

248 the Cascadia accretionary wedge in the Olympic Mountains, northwest Washington 
State: Geological Society of America Bulletin, v. 110, p. 985-1009, doi:10.1130/0016-7606(1998)110<0985:LCEOTC $>2.3 . C O ; 2$.

251 Carson, R., 1970, Quaternary Geology of the South-Central Olympic Peninsula, 252 Washington [Ph.D. Thesis]: Seattle, Washington, University of Washington, $67 \mathrm{p}$.

253 Cooke, M.L., and Dair, L.C., 2011, Simulating the recent evolution of the southern big

254 bend of the San Andreas fault, Southern California: Journal of Geophysical

255 Research, v. 116, p. B04405, doi:10.1029/2010JB007835.

256 Crouch, S.L., and Starfield, A.M., 1983, Boundary Element Methods in Solid Mechanics:

257 With Applications in Rock Mechanics and Geological Engineering: London, U.K., $258 \quad$ George Allen \& Unwin, 322 p.

259 González, G., Salazar, P., Loveless, J.P., Allmendinger, R.W., Aron, F., and Shrivastava,

260 M., 2015, Upper plate reverse fault reactivation and the unclamping of the megathrust during the 2014 northern Chile earthquake sequence: Geology, v. 43, p. 671-674, doi:10.1130/G36703.1.

263 Hyndman, R.D., and Wang, K., 1993, Thermal constraints on the zone of major thrust

264 earthquake failure: The Cascadia Subduction Zone: Journal of Geophysical

265 Research. Solid Earth, v. 98, p. 2039-2060, doi:10.1029/92JB02279.

266 Kelsey, H.M., Engebretson, D.C., Mitchell, C.E., and Ticknor, R.L., 1994, Topographic

267 form of the Coast Ranges of the Cascadia Margin in relation to coastal uplift rates

268 and plate subduction: Journal of Geophysical Research. Solid Earth, v. 99, p. 12245-

$269 \quad$ 12255, doi:10.1029/93JB03236. 
270 Litchfield, N., and Berryman, K., 2006, Relations between postglacial fluvial incision

271 rates and uplift rates in the North Island, New Zealand: Journal of Geophysical

272 Research, Earth Surface, v. 111, p. F02007, doi:10.1029/2005JF000374.

273 Loveless, J.P., and Pritchard, M.E., 2008, Motion on upper-plate faults during subduction

274 zone earthquakes: Case of the Atacama Fault System, northern Chile: Geochemistry

275 Geophysics Geosystems, v. 9, Q12017, doi:10.1029/2008GC002155.

276 Mazzotti, S., Dragert, H., Hyndman, R.D., Miller, M.M., and Henton, J.A., 2002, GPS

277 deformation in a region of high crustal seismicity: N. Cascadia forearc: Earth and

278 Planetary Science Letters, v. 198, p. 41-48, doi:10.1016/S0012-821X(02)00520-4.

279 McCaffrey, R., 1993, On the role of the upper plate in great subduction zone earthquakes:

280 Journal of Geophysical Research. Solid Earth, v. 98, p. 11953-11966,

281 doi:10.1029/93JB00445.

282 Meade, B.J., and Loveless, J., 2009, Block Modeling with Connected Fault-Network

283 Geometries and a Linear Elastic Coupling Estimator in Spherical Coordinates:

284 Bulletin of the Seismological Society of America, v. 99, p. 3124-3139,

285 doi:10.1785/0120090088.

286 Melnick, D., Bookhagen, B., Strecker, M.R., and Echtler, H.P., 2009, Segmentation of

287 megathrust rupture zones from fore-arc deformation patterns over hundreds to

288 millions of years, Arauco peninsula, Chile: Journal of Geophysical Research. Solid

289 Earth, v. 114, p. B01407, doi:10.1029/2008JB005788.

290 Mitchell, C.E., Vincent, P., Weldon, R.J., and Richards, M.A., 1994, Present-day vertical

291 deformation of the Cascadia Margin, Pacific Northwest, United States: Journal of

292 Geophysical Research, v. 99, p. 12257-12277, doi:10.1029/94JB00279. 
293 Pazzaglia, F.J., and Brandon, M.T., 2001, A Fluvial Record of Long-term Steady-state

294 Uplift and Erosion Across the Cascadia Forearc High, Western Washington State:

295 American Journal of Science, v. 301, p. 385-431, doi:10.2475/ajs.301.4-5.385.

296 Personius, S.F., 1995, Late Quaternary stream incision and uplift in the forearc of the

297 Cascadia subduction zone, western Oregon: Journal of Geophysical Research. Solid

298 Earth, v. 100, p. 20193-20210, doi:10.1029/95JB01684.

299 Quinault River Basin [lidar file], 2012, Seattle, WA: USGS and Puget Sound Lidar

300 Consortium. Available: Puget Sound Lidar Consortium, Seattle, WA

301 http://pugetsoundlidar.ess.washington.edu/index.htm (accessed September 2014).

302 Sherrod, B., and Gomberg, J., 2014, Crustal earthquake triggering by pre-historic great

303 earthquakes on subduction zone thrusts: Journal of Geophysical Research. Solid

304 Earth, v. 119, p. 1273-1294, doi:10.1002/2013JB010635.

305 Southwest Washington [lidar file], 2009, Portland, OR: Oregon Department of Geology

306 and Mineral Industries. Available: Puget Sound Lidar Consortium, Seattle, WA

$307 \mathrm{http}: / /$ pugetsoundlidar.ess.washington.edu/index.htm (accessed September 2014).

308 Thomas, A., 1993, Poly3D: A three-dimensional, polygonal element, displacement

309 boundary element computer program with applications to fractures, faults, and

310 cavities in the Earth's crust [Ms. Thesis]: Stanford University, 69 p.

311 Thorson, R.M., 1989, Glacio-isostatic response of the Puget Sound area, Washington:

312 Geological Society of America Bulletin, v. 101, p. 1163, doi:10.1130/0016-

313 7606(1989)101<1163:GIROTP>2.3.CO;2. 
314 Walsh, T.J., and Logan, R.L., 2007, Results of trenching the Canyon River fault,

315 southeast Olympic Mountains, Washington: Geological Society of America

316 Abstracts with Programs, v. 39, poster No. 22-4.

317 Wang, K., Mulder, T., Rogers, G.C., and Hyndman, R.D., 1995, Case for very low

318 coupling stress on the Cascadia Subduction Fault: Journal of Geophysical Research.

319 Solid Earth, v. 100, p. 12907-12918, doi:10.1029/95JB00516.

320 Washington State Department of Ecology, 2015, Washington State Well Log Viewer:

321 https://fortress.wa.gov/ecy/waterresources/map/WCLSWebMap/default.aspx

322 (accessed November 2015).

323 Wells, R.E., Weaver, C.S., and Blakely, R.J., 1998, Fore-arc migration in Cascadia and

324 its neotectonic significance: Geology, v. 26, p. 759-762, doi:10.1130/0091-

$325 \quad 7613(1998) 026<0759: F A M I C A>2.3 . C O ; 2$.

326 Witter, R.C., Givler, R.W., and Carson, R.J., 2008, Two Post-Glacial Earthquakes on the

327 Saddle Mountain West Fault, Southeastern Olympic Peninsula, Washington: Bulletin

328 of the Seismological Society of America, v. 98, p. 2894-2917,

329 doi:10.1785/0120080127.

330

331 FIGURE CAPTIONS

332

333 Figure 1. Holocene upper plate faults, major drainages, and Cordilleran Ice sheet limit

334 (Thorson, 1989) in the Olympic Mountains, WA. CRF-Canyon River fault; SMFZ -

335 Saddle Mountain fault zone. Inset: Cascadia subduction zone with relative plate motions.

336 JDF - Juan de Fuca plate; PAC - Pacific plate. 
338 Figure 2. Map of the Canyon River fault (CRF) scarps, topographic profile locations, and

339 terrace ages (yellow triangles). A) Vertical separation (Vs) and vertical separation rates

340 (Vsr) across the CRF from terrace profiles. B) Examples of scarp profile vertical

341 separation. C) Profile of Qt5, showing two possible vertical separations across the CRF.

343 Figure 3. A) Map view of Qt5 terraces. Red and blue gradient shows map view of

344 modeled Canyon River fault (CRF) uplift rate, with local minimum coinciding with the

345 river location. Contours are predicted regional uplift rate $(\mathrm{mm} / \mathrm{y})$ from subduction

346 coupling. B) Qt5 tread and strath elevations with uncertainty (shading) versus valley

347 distance. C) Modeled total uplift rate and uncertainty (shading) due to subduction

348 coupling and CRF slip compared to terrace Qt5 incision rates with uncertainty (shading).

349 Inset: Regression of modeled total uplift and incision rate values at $>20 \mathrm{~km}$ valley

350 distance showing positive correlation.

351

352 1GSA Data Repository item 2017xxx, Figures DR1-DR14 and Tables DR1-DR5 and

353 supplementary text (additional model figures, field and sample data, and detailed

354 methods), is available online at http://www.geosociety.org/datarepository/2017/ or on

355 request from editing@geosociety.org. 
TABLE 1. OPTICALLY STIMULATED LUMINESCENCE RESULTS

\begin{tabular}{|c|c|c|c|c|c|c|c|c|}
\hline \multirow{2}{*}{$\begin{array}{l}\text { Sample } \\
\text { number }\end{array}$} & \multirow{2}{*}{$\begin{array}{c}\text { Map } \\
\text { unit }\end{array}$} & \multicolumn{2}{|c|}{ Location } & \multirow{2}{*}{$\begin{array}{c}\text { Elevation } \\
(\mathrm{m})\end{array}$} & \multirow{2}{*}{$\begin{array}{c}\text { Valley } \\
\text { distance } \\
(\mathrm{km})\end{array}$} & \multirow{2}{*}{\multicolumn{2}{|c|}{$\begin{array}{c}\text { Age } \pm 2 \sigma \\
(\mathrm{ka})\end{array}$}} & \\
\hline & & $\begin{array}{l}\text { Lat } \\
\left({ }^{\circ} \mathrm{N}\right)\end{array}$ & $\begin{array}{l}\text { Long } \\
\left({ }^{\circ} \mathrm{W}\right)\end{array}$ & & & & & \\
\hline WYN-04 & Qt7 & 47.3423 & 123.6409 & 165 & 5.8 & 8.9 & \pm & $\overline{2.4}$ \\
\hline WYN-06 & Qt5 & 47.3417 & 123.6507 & 194 & 6.0 & 14.8 & \pm & 4.0 \\
\hline WYN-07 & Qt5b & 47.1006 & 123.6848 & 57 & 35.0 & 14.6 & \pm & 3.5 \\
\hline WYN-08 & Qt5 & 47.0583 & 123.6928 & 42 & 39.8 & 22.9 & \pm & 6.2 \\
\hline WYN-15 & Qt5 & 47.2121 & 123.6355 & 107 & 20.9 & 13.5 & \pm & 6.3 \\
\hline WYN-16 & Qt5 & 47.2121 & 123.6355 & 109 & 20.9 & 13.5 & \pm & 4.0 \\
\hline WYN-17 & Qt4 & 47.3740 & 123.6147 & 253 & 1.2 & 32.2 & \pm & 9.7 \\
\hline WYN-18 & Qt4 & 47.3740 & 123.6147 & 253 & 1.2 & 14.7 & \pm & 6.7 \\
\hline WYN-19 & Qt8 & 47.3419 & 123.6407 & 162 & 5.8 & 7.8 & \pm & 2.4 \\
\hline
\end{tabular}

357

Page 17 of 17 


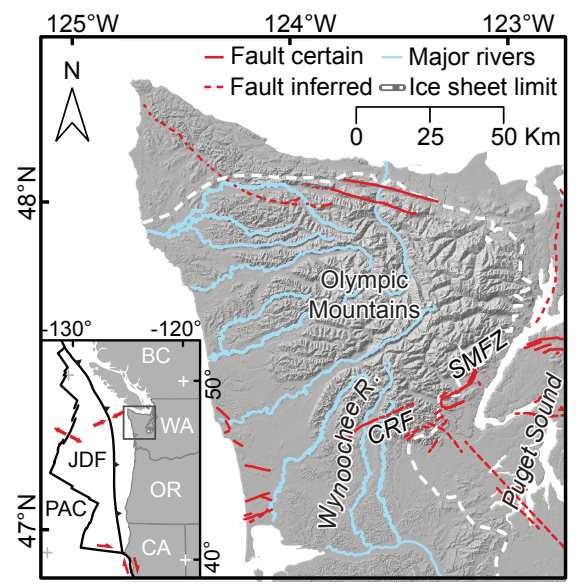

Fig. 1, Delano et al. 


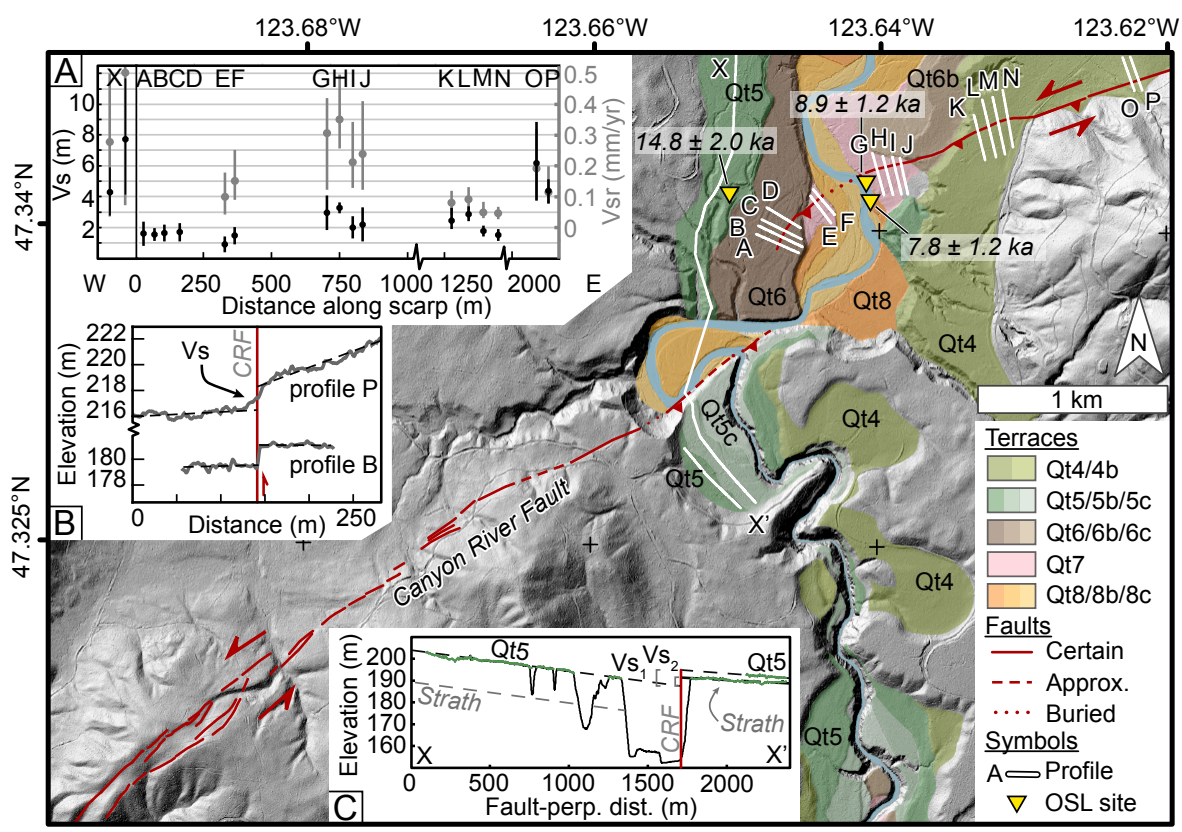

Fig. 2, Delano et al. 

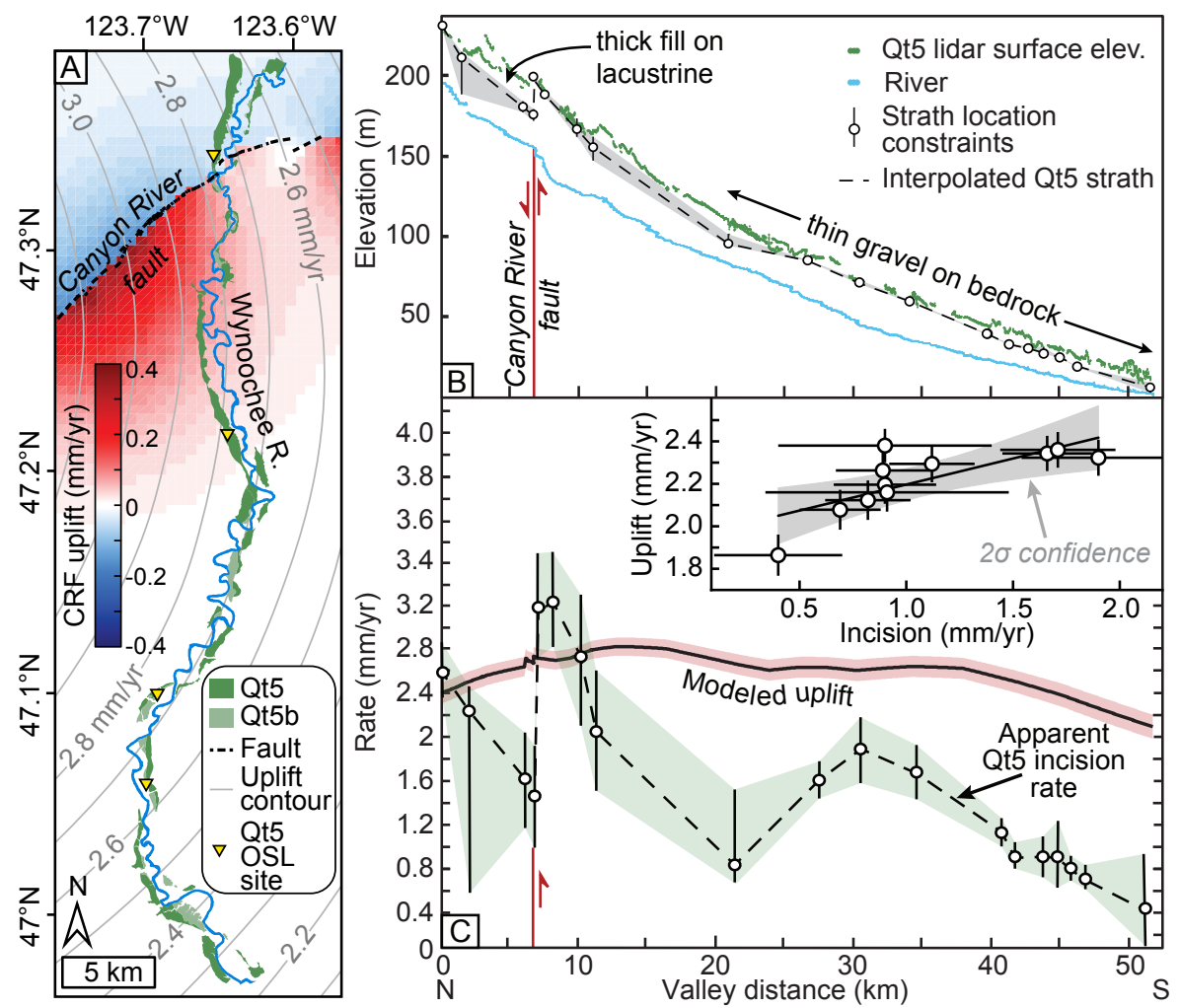

Fig. 3, Delano et al. 